\title{
Analysis of Corporate Web Sites as a Public Relations Tool, with Regards to Knowledge Management Process
}

\author{
Assist. Prof. Dr. Betül Özkaya \\ Marmara University, Faculty of Communication, istanbul \\ betulozkaya@marmara.edu.tr \\ Assist. Prof. Dr. Selda Ene \\ Marmara University, Vocational High School of Social Sciences, İstanbul \\ seldaene@marmara.edu.tr
}

Doi:10.5901/ajis.2013.v2n8p69

Abstract

The corporations that wish to create a successful web site and to perform their public relations activities on virtual environment, need to develop a system that can enable them to use the knowledge flow between the target audience and the corporation, the interaction among them and the knowledge inside and outside of the corporation effectively. For this purpose, a knowledge management system needs to direct the three important phases which are: knowledge sharing between the corporations and the target audience on web environment, knowledge acquisition and dissemination of the knowledge, in an interactive way. Implementation of an knowledge management process that includes aforementioned three phases will both enable the corporation to be in an interaction with the target audience and to obtain fast feedback. For this purpose, this study will examine the virtual public relations activities, that are implemented via their corporate web site, of first 20 companies who are chosen as Turkey's most popular companies of 2012, by using content analysis, with regard to knowledge management process. So that, in order for the corporations to be distinguished from their competitors by gaining awareness before their target audience and to gain effective results in public relations activities, an establishment of a guide for the management of continuous knowledge flow that is generated inside and outside of the corporation, is aimed.

Keywords: Public Relations, Corporate Web Site, Knowledge Management Process

\section{Introduction}

With the internet usage, which is indispensable in today's communication, becoming widespread in every field, public relations operators found the opportunity to interact with their target audiences on face to face basis (Jo and Jung, 2005: 25). One of the most efficient tools that enable this kind of communication between the corporations and target audience are the corporate web sites which enable the virtual presentations and are defined as the media of the new age. In this intense competitive environment, corporations having a web site, is as natural as them having a telephone number. For this reason, it is clear that establishment of a web site is necessary and important for the corporations (Er, 2008: 88).

One of the most important mediums of the intense communication efforts that are performed on corporate level are the web sites (Alan and Sungur, 2007: 131). Corporate web sites, which are also identified as corporations' windows to the outside world, communicate to the target audience about the identity of the company, its history, the mission, vision, goal and purpose of the corporation, about the products/services offered, contact information of the corporation, the sale of products/services online and even have the structure to provide after sale services (Yeygel, 2005: 79). In other words, when the structure of the corporate web sites that offer different opportunities in one place, is analysed, it can be seen that promotional knowledge is presented. Due to these characteristics, web sites, for many corporations, carry the importance of a brochure and the web sites are seen as an promotion tool for the corporation. However, since there are no limits on Internet in terms of promotional opportunities, it is desired to take advantage of this interactive environment which can communicate with target audiences in effective and productive ways. In this regard, the ability for the corporations to use this knowledge flows with regard to knowledge that is within the corporation or outside of the corporation, interactions among the target audience, holds a critical importance in terms of success of public relations activity. Therefore, it is a fact that the corporations need a knowledge management system in order to accomplish these on a web environment. 
In this study, by emphasizing the importance of knowledge management process in the establishment of corporate web sites to be used as a public relations tool, the virtual public relations activities of the most popular 20 companies of 2012 in Turkey will be analysed by using content analysis in terms of three phases of knowledge management process.

\section{Corporate Web Sites as Public Relations Tools}

Public relations is one of the fields of occupation that is growing increasingly popular. Public relations, which expresses the process of influencing the public opinion and being influenced by it, is the sum of the efforts that a corporation employs in order to become integrated with the society. However, the public, which every corporation interacts with, offer differences. For instance, for a government, public is every individual that reside in a country; for an institution they are its own members; for a sports club, they are its fans and for a company, public is all individuals and institutions that are within the organization and those who are outside of the organization, but have a link with the organization itself (Sabuncuoğlu, 1998:4).

The most basic function of the public relations is to establish a contact and to manage the communication between the corporations and the target audience. Whether it is informing the public or the need of connection with the managers, mutual dialogue, influencing individuals, being influenced by them, in other words, two-way communication and feedback constitute the essentials of public relations (Canöz, 2008: 358). Even the medium and tools which are used for this reason in public relations emerge to be intended for the needs of different times, emergence of the Internet necessitated another train of thought in public relations and to rearrange the conventional public relations techniques. For this reason, Internet not only brought a radical change to the practice of public relations, but also enabled the testing and evaluation of old and new theoretical structures.

With the Internet being used in daily life, first Web 1.0 era, which has developed in 1989 by Tim Berners-Lee, had started, followed by the Web 2.0 era (interactive web), introduced by O'Reilly Media in 2004. The Web 1.0, which included only content host and content reader, was comprised of Internet sites which seem very visceral when compared to web sites of today. In this era when the users were in the position of data receiver, there was an unilateral communication between the web sites and the users and the content of the web sites could only be controlled by the web hosts. There were no interaction between the users and the web sites in Web 1.0 era and the inefficient technical substructure of Web 1.0 era sites led to the birth of more user-friendly Web 2.0. In a sense, this is a mutation in design and software technologies of the Internet world (Özkaya, 2012:357).

Internet, which is one of the most important building blocks of communication revolution and its usage technology Web 2.0, are not only mass mediums that can spread the knowledge and contribute without an intercessor, but also a natural medium which they can monitor the target audience and the chats that they contribute and gain feedbacks. (Özkaya, 2012: 358). And gaining feedback is the most appropriate starting point of two-way communication that can be established between corporations and target audiences.

The Internet and the web are important tools for public relations when appropriately planned to be used in the field of promotion. The messages which the corporations dispatch from different communication channels are collected at one address in the Internet medium. The web is a new communication tool in which millions of voices interact with each other in the multimedia communication environment. It is a powerful communication tool for the public relations experts and can be dangerous for the corporations. When used correctly, the web medium can be the most effective communication tool for the purpose of establishing a relationship between the corporation and the target audience and it involves all kinds of communication types, such as text, voice, graphic, photo, animation, music or video. Most importantly, web enables an establishment of information personalization and interactive communication for the large masses like never before. In the context of information technologies, all kinds of web based communication, such as e-mail, chat rooms, can be used to communicate effectively with employees, partners and volunteers (Sayımer, 2008: 71).

Web sites are one of the most frequently used and most effective tools that serve to make connections and to maintain these with corporations (Taş ve Kestellioğlu, 2011: 12). For the corporations which need to shape their past and their future, a web site is one of the most crucial communication mediums. As a beneficial public relations tool, the web sites of corporations help to increase the awareness and understanding of the target audience in terms of corporations, product and services. More importantly, when its potential to improve the mutual communication is considered, it undertakes an important role in terms of communication management and even, knowledge management (Güçdemir, 2010: 61).

Corporations are able to convey all of their public relations activities to their target audiences with the presentations on their web sites. As corporations' most effective public relations tools, the web sites, with their interactive features that 
enable two-way communication, are deemed as one of the most important indicators of institutionalization.

\subsection{Establishment of Corporate Web Sites}

The Internet and the web sites, without a doubt, provide endless possibilities for corporations. In this context, establishment of a web page means prestige, confidence and new customers for a corporation (Şencan, 2013: 105). Until today, the purpose of most of the corporations that has created a web site is to have a place in cyber space, to communicate with the target audience, to promote the business, to reach to the target audience swiftly and securely, to make sales online, to reduce their customer service and advertisement costs, to improve the communication with employees, to enter international markets, to reinforce corporate identity and corporate image (Okay and Canpolat, 2006: 448). In a study, made by Fortune magazine to determine the utilization purposes of the web sites of first 500 companies, it has been determined that many companies use their web sites to establish an internal communication and corporate image, to make direct sales or to reinforce their public relations activities (Hill and White, 2000: 31). However, there should be a difference between a web site that aims for promotional purpose and a web site that aims for sales purpose, in terms of design and content (Türk and Güven, 2007: 56-57). In the case of establishment of public relations driven corporate web pages, the goal is to make the visitors stay on the web page for a certain period of time, have a good time while surfing the site, interact with the corporation and make this process continuous. When a web site is created according to these needs, it can be stated that an effective communication with the target audience can be maintained via corporate web site (Alikılıç, 2011: 63).

The decision to be on cyber space and a creation of a web site should be managed professionally by the public relations experts. Accordingly, when corporations create web sites, they should try to make a positive perception by minding some of the basic principles (Sayımer, 2008: 90). These principles can be summarized as follows (Falk, 2000: 37-40; Er, 2011: 90-91;Yılmaz, 2011: 141; Theaker, 2006: 371; Güçdemir, 2010: 61-62);

- A web site should be genuine and easily accessible.

- The design of the pages should match the content and the purpose.

- All the links that are present on the web page should be accessible. In other words, there should be no dead links on the pages, because badly designed links might strike a negative impression for the user.

- The directional keys should be designed effectively and these keys should guide the users in a correct manner.

- Information should both be read easily and conveyed appropriately, with logic alignment. When read from left to right, the information which needs to be conveyed as priority should be located on the left side of the screen.

- Information should be presented as fast as possible on the screen. Because, this is the first time the user and the corporation meet and the web site should fully opened in 8 seconds.

- Should the user need more information, he/she should access these easily and inbound questions, requests and expectations should be answered in an absolute manner.

- Color schemes used on the page are highly important. Because they possess the characteristic to congest the time of the users, along with representing the corporation. It is important to prefer standard colour patterns that suit the computer best. When the format which the colours enable is taken into account, there shouldn't be a one-dimensional tameness on the screen.

- All graphic and design works that are prepared should be understandable by the target audience. Generally, the users abandon the web sites which they find to have complex interfaces and prefer another web site that has a similar content. This affects the utility of some web pages in a negative way.

- An aesthetic and functional integrity should be presented between all the elements which are comprised on the design of the web page. Sites that have deranged designs and are unattractive, are not favoured by the target audiences.

- In terms of making an impact, sound and effects make a web site more effectual.

- Latest developments regarding the space should be regularly followed and the web sites need to be updated in certain intervals. There can be no success stories for the web sites that are not updated.

- Web site should be secure and should convey necessary security information. Since the users need to be certain that the information they enter on the forms or the credit card numbers will not be shared with others, the web site should include links such as privacy policy, security policy and security certification.

- In order to increase the visit times, interactive time spending times, there should be some elements are 
encouraging on the site, such as awards, games (like advergame) wallpapers, puzzles, competitions, etc.

- There should be a 'what's new' section in order for the users to find new additions and access them directly.

- For those individuals who wish to contact with the corporation, telephone, address and fax details should be included.

Users who surf on the web sites are engaged in more lively activities than the ordinary people of today. When this reality is looked upon from the perspectives of the corporations, the corporation which possess an ordinary web site is not deemed as 'a corporation that exist in digital medium'. It is not sufficient enough for a corporation to create a web site and garnish it with attractive animations and thus, to attract Internet users. When we look at most corporate web sites, we see that they have good designs and possess attractive features such as colour, animation and photography. This is the main point which the public relations experts lose their bearings. The user, who has visited a corporate web site, in fact has found the site via search or has entered the site in hopes of finding information which he/she is curious about. However, when the Internet user cannot access this information or is bored due to slow web site and become distracted (Özkaya, 2010: 459), he/she abandons the site all together and never comes back. Therefore, the corporations should give the users a purpose to gain information, re-visit the site in the future, suggest the site to others, interact with each other and they should concentrate in this regard and make programs (Alikılıc, 2011: 65-66). In other words, in order to communicate with the target audience, they should motivate their target groups with regard to continuous web sites visits.

Halligan and Shah (2010: 12-13) have given their suggestions by drawing a successful analogy in creation of an active and successful web site. They have compared New York, which is a metropolis and has become a world city, has three airports, a large intercity bus garage and a metro connections with wide networks and two big train stations that connect the city to all other countries, with Massaschussets state's Wellesbey city that has only a highway within city limits and they have identified both of them with corporate web sites. Whilst talking about the circulation network of the city, the highways, planes, trains, busses are in fact search engines which has to other sites and not only they lead the traffic, but they also transfer passengers. For this reason, it is important for the corporations to decide between these two given cities and to choose the network of either city, in order to create a successful corporate web site. In addition to these, the public relations experts need to include understandable, creative, interesting, current and valuable content, in order to be attractive for the Internet users and they need to enable the partition and involvement of those contents, when they create the representative or even the showcase of the corporate image and brand value on the web (YIImaz, 2011: 140). Moreover, there is the topic of different perception choices of target audience in regards to given contents. While some of them prefer reading, some will value visual content more. Thus, there needs to be appropriate image, audio or video content developed and the same content should be distributed to different groups with different formats (Güçdemir, 2010: 63). In this way, with their developed web site strategies, the corporations should enable continuous interaction and develop rich content that will attract the attention of the users, entertain them and more importantly, that will secure the continuity of these, in order to hold visitors in long term (Scott, 2009: 122).

\subsection{Features That Need to Be Included in a Corporate Web Site}

While the web sites, for the corporations, are tools that reduce the uncertainty, enable the communication with target audience and supervision of relations, for target audiences, there are tools that enable them to recognize and to understand the corporation in a better way. Therefore, web sites help corporations to conduct their public relations duties efficiently by enabling the publication of topics such as media relations, investor relations, human resources/career, institutive social responsibility, along with knowledge regarding the consumers and corporate knowledge. All these topics constitute the basic topics which the corporations need to include on their web pages.

In media relations, which is one of the topics included in the web sites, such knowledge like press releases, archive and photograph are included, which can be used in news creation process. Under investor relations, financial analysis, statistics, stock knowledge and annual reports for the investors, can be found which directly targets the investor group. Under human resources or career topic, there will be knowledge regarding online job applications intended at potential employees, corporate employment conditions and internship possibilities are included. Another topic, which is corporate social responsibility, includes the social responsibility attitude of the company and the social investment oriented activities are introduced. And the knowledge that is aimed at the consumers that visit the web site contain knowledge regarding the product, brands and services (images, graphics, campaigns, 'what's knew' sections, etc.). The history of the corporation, its vision and mission, activity areas, its insigne/logo, contact knowledge (address, telephone, fax, etc.) employee list, messages from the administration, directors and partners, if any, will be under the corporate section and this section is specifically designed as to be an promotional section for the general public for the corporation. (Robbins and Stylianou, 
2002: 207; Sayımer, 2006: 169-170; Yurdakul, 2006: 209-210; Yılmaz, 2011: 140).

Today, as the most powerful tool with regard to self-promotion of the corporation, the other features that need to be included on the corporate web sites are: site map registration form, online survey form, contact form, PR contact name, his/her e-mail address, phone and fax number, chat rooms, site update time, online order/purchase form, frequently asked questions, number of visitors for the site, newsgroups, links for relevant web sites, links to social networks that belong to the corporation, etc. (Sayımer, 2006: 163-164). Therefore public relations will be able to provide knowledge to news corporations, make contact with all target audiences, gain knowledge about different target groups, establish a status symbol for the corporation, make online sales, reach international markets, reach many people who are surfing the net and to perform other public relations tasks through the web site that has the abovementioned features (Türk and Güven, 2007: 55). If the corporations, that wish to perform public relations activities on virtual platform, consider the abovementioned features when creating web sites, they will be rewarded with a sustainable competitive advantage. As is seen, due to combination of different contents in an integrated platform, public relations on the Internet require a strategic and attentive planning.

\section{The Importance of Knowledge Management Process in Establishment of Corporate Web Sites as Public Relations Tools}

In today's constantly globalizing world, both constant and swift alteration and uncertainty and economic, social, political and technological alteration and development make it hard for the organizations to stand tall in this fierce competitive environment. In such an environment, the success rate for the corporations to reach their targets and to seize on their intended successes will depend on their ability to manage the knowledge. Because, knowledge has become the most important production factor in today's world (Çetinkaya, 2012: 157). For this reason, this age is referred as knowledge age, the society is referred as knowledge society and the individuals are referred as knowledge employees. In such a period, it will not be a mistake to see the knowledge management as the most important element of the corporate management (Selvi, 2012: 202-203).

In the new society, which the new economy has given birth to, factors such as the capacity to access knowledge, the opportunity and the ability to adhere to knowledge and the ability to benefit from the knowledge, will determine the socio-economic positions of individuals and corporations (Clarke, 2001: 189). In such an economic and social structure where the knowledge plays a central role, the corporations that exist in this structure will only survive if they are successful in determination and evaluation of knowledge sources, production of organizational knowledge, procurement and development of knowledge, sharing and usage of knowledge. Therefore, the corporations need to manage their knowledge efficiently.

\subsection{Knowledge and Knowledge Management}

In today's business world, the speed of alteration is gradually increasing and this makes it essential to learn and to gain knowledge. Knowledge is information that is organized in a personalized way. It is integrated with previous knowledge which has been obtained by learning and experience. In other words, knowledge is the enriched state of information through comment, analysis and context. Information, on the other hand, is the state of associated, organized and process data. Just like the way information is created from data, knowledge is created from information. The information flow between the people enables the creation of knowledge. If gained information carries a value, it is integrated with the fund of knowledge of the person who gains it and is added to the knowledge storage. If it does not carry any value, it is rejected and erased (Barutçugil, 2002: 58).

Knowledge shows itself in routine works, processes, applications and norms in the corporations, not only in documents or folders (Davenport and Prusak, 2001: 27). In order to survive and to maintain their competitive edges, the corporations need to manage their knowledge efficiently. In this context, the organizations that are able to manage their corporate knowledge in a certain system not only reach their goals easily, but also achieve the opportunity to compete and resist the competition in this constantly developing world. The corporations which comprehend the importance of knowledge and develop and use these, can see that these short term steps are returned to them as added values. For this reason, many corporations that desire to improve their organizational performances make an effort to produce, to share and to use their corporate knowledge sufficiently. In exchange for this effort, the corporations transform into more productive and procreative organizations and they are able to implement structural changes that satisfy their employees and the individuals who they provide services to (Odabaş, 2003: 367). 
For the corporation, knowledge management is a system that paves the way for acquisition, storage and sharing of knowledge. It is possible to reach different goals regarding the usage of a knowledge management system in a corporation. These can be listed as: measurement, establishment of a synergy between faster work processes and employees, revealing hidden accumulations and knowledge for the benefit of organizational performance and increasing the intellectual capital of the corporation (Yalçın and Ene, 2008: 245). Intellectual capital is a concept which is comprised of correlative interaction of three components: basic human capital (the sum of knowledge, ability and behaviour of employees), structural capital (the sum of tools, means and processes that the corporation possess) and customer capital (the value that is attributed to the relationship between the customers and the company) (Göksel and Baytekin, 2008: 81).

Generally, the knowledge management expresses an organization process that possesses a perspective which aims an efficient usage of the information for the targets of the organization and an organization process which possesses efforts with regard to this perspective. According to another description, knowledge management is the act performed by the organization, to classify, analyse, interpret and include the data which the organization have or acquired externally, to the organization processes. According to Zaim (2005: 80), knowledge management is the development of a conscious and systematic strategy that enables to share and to organize the correct knowledge, at the right time, with the right people.

In order to understand knowledge management, it is required to analyse the basic steps and the basic acts in the application. Here, four basic steps, like conceptualizing, reflection, action planning and inspection, are discussed (Barutçugil, 2002: 71).

- Conceptualizing: To perform an investigation and classification study, in order to find which knowledge assets a corporation has. To investigate where the knowledge assets are located, in what form they are discovered, how accessible they are and their benefits.

- Reflection: To analyse to see what kind of a benefit can knowledge bring to the corporation. To analyse the opportunities of using knowledge assets, to determine the usage impact.

- Action Planning: To determine the necessary acts in order to obtain more added value. To resolve the way that the practices will be planned, started and followed in order to use knowledge assets. To integrate knowledge existence with relevant activities.

- Inspection: To evaluate the knowledge usage in order to provide added value. To determine if the knowledge existence provides the added value and to resolve the means to store for repetitive usage. To evaluate if the usage creates new opportunities.

\subsection{Knowledge Management Process}

Knowledge represents a dynamic process, not a static entity. Many corporations across the globe, having many different characteristics, have recognized the importance of knowledge as the source and the importance of knowledge management as the process itself. Discussion of knowledge management as a corporation process is an approach which has been widely accepted since 1990s. This can be also expressed as a process in which the corporations establish their own corporate and collective knowledge. In this context, it can be said that the knowledge management is an applicable and extensive process for many different organizations, from private sector to public sector, from universities to military institutions.

Filius et al. (2000: 287-288), have stated that basic activities, such as adoption (procurement and development), internalization (storage and protection), sharing (transfer and generalization) and usage (application, evaluation) of knowledge, are virtually contained in the knowledge management processes of all organizations, if not by name. As for Wiig (1997: 6-14), knowledge management processes are expressed as collection of knowledge from various sources, procreation, transformation to different knowledge, dissemination within the corporation and operation of knowledge and finally valuing its significance. And Malhotra (2003: 68). has determined six steps, in order to benefit from the knowledge management process as much as possible. These are, being conscious of knowledge, determining the purpose of knowledge, application, dissemination, development and storage. Karakaş and Yaralı (2004: 551) state that the knowledge management process is comprised of various steps, such as knowledge gain, storage of knowledge, dissemination of knowledge, interpretation and application of knowledge.

There are three basic forces which support the consecutive phases of knowledge management process and enable these phases to materialize successfully or fail them. These are technology, processes and culture (Barutçugil, 2002: 71; Şencan, 2013: 27);

- Technology: It is a platform that compiles, cultivates, publishes all information of customers, employees and 
corporation - so that it also includes the sub structure of communication and information processing center. It represents Internet, intranet, multimedia tools and technology. The importance of technology is that it enables everyone to access information 24 hours a day, 365 days a year, from anywhere.

- Processes: They are standards, reporting systems, decision making and problem solving processes, performance evaluation and awarding systems that support the corporation culture and provide its adaptation to other work systems.

- Culture: The context of attitude and behaviour patterns, beliefs and values system, management styles, folkways, the vision of the corporation and its long term goals should be reflected in terms of culture.

Knowledge management owes its development (in terms of instrumental), mostly to information technologies. Many organizations have recognized the necessity of knowledge management in application and along with swift developments in the communication and information technologies, the sensibility of these organizations to knowledge management studies have increased.

\subsection{Corporate Web Sites as a Public Relations Tool, in the Context of Knowledge Management Process}

The Web is a knowledge platform that provides various kinds of services that make life easier (Şencan, 2013: 100). Since the first step of establishing good relations with target audience and developing them, is to provide them knowledge, it is important to emphasize the importance of the web, in the context of public relations.

The environments, in which the knowledge exists intensely today, are the Internet and the web sites which are integral parts of the Internet (Uçak and Çakmak, 2009: 279). With their knowledge transfer and sharing functions, the active usage of the web sites, which are one of the most effective tools that enable communication between corporations and target audience and provide virtual presentations, by the target audience, provides an important role in determining the activity of public relations (Firlar, 2010: 154). Particularly today, the corporations make great efforts, in terms of time and cost, to establish a positive image. For this reason, corporate web sites are one of the most important image creation tools of the corporation in 21. century (Güçdemir, 2010: 61).

For those corporations who create a web site and desire to perform public relations in the virtual environment; it is important for them to establish a system where they can efficiently use inner and outer corporation knowledge, the interaction among the target audience and knowledge flow with the corporation, in order to be successful. In this context, the knowledge management system that is to be developed requires an interactive management of three important phases between the corporation and target audience in the web environment: "knowledge dissemination", "knowledge acquisition" and "knowledge sharing" (Nah et al., 2002: 127).

\subsubsection{Dissemination of Knowledge}

Knowledge is acquired from the internal activities that are in organizational level or form external sources that have communications with the business structure. Companies transform the necessary information to knowledge when they require, using the relations with inner and external environments. (Selvi, 2012: 204).

Dissemination of knowledge is expressed as a process in which the information gathered from different sources is shared. To enable the distribution of knowledge from the corporation web site to the target audience, the web site should be configured according to the topics below:

- Different language option

- Site map

- In-site search function

- Update date of the site

- Link connection

- Media relations (press room)

- Corporate knowledge

- Knowledge regarding investors

- Knowledge regarding consumers

- Knowledge regarding the corporate social responsibility studies

- Knowledge regarding human resources

- Privacy knowledge

- Security knowledge 


\subsubsection{Knowledge Acquisition}

To monitor and to gain knowledge of the impressions and experiences of target audience on the web site constantly, there should be a substructure of the web site with regards to some topics:

- Registration (i.e. registration information and password)

- Online order / purchase form

- Contact form (contact us; to obtain online user complaints, suggestions, questions, comments and satisfaction dispatches)

- Online survey form

\subsubsection{Knowledge Sharing}

For the continuity of the companies, it is crucial to know the time of knowledge sharing, which knowledge is being shared, why and to what extent. Since possession of knowledge means possession of prerogative power, it can be said that sharing this power could induce power loss or gain (Selvi, 2012: 205).

The knowledge flow between the target groups and the corporation and the flow among the target groups is relatively important, in terms of the efficiency of public relations studies that are practiced on Internet environment. Instantly replying to written messages or replying via e-mail afterwards is an important indicator as to how the target audience is valued and an indicator of service aspiration and speed. And this will increase the satisfaction and confidence of the target group.

- Visitor count of the web site

- Service hotline

- Chat room

- Frequently asked questions

- E-mail link

- Forum and newsgroups (newsgroups are Internet discussion forums where the user groups that have fields of interest talk about many topics, ranging from technology to politics).

- PR contact (the contact person name, his/her e-mail address, telephone and fax number is rather a necessity for the press)

- Corporate blog

- Job application form

- Fun (i.e. advergame, awards, music)

- Links to social networks belonging to the corporation (ie. Facebook, Twitter, Linkedin, Flickr)

\section{Analysis of Corporate Web Sites as Public Relations Tool, in the Context of Knowledge Management System}

\subsection{Purpose of the Study}

The corporations, who desire to create a web site and perform successful public relations activities on the web, need to establish a system where they can effectively use the knowledge inside and outside of the corporation, the interaction between themselves and the target audience and knowledge flow within the corporation. In this context, a knowledge management system that has been established, require an interactive management of three important phases - called "dissemination of knowledge", "knowledge acquisition", "knowledge sharing" - between the corporation and target audience on the web environment. The application of the knowledge management system, which includes the aforementioned three phases, will both enable the corporation to have constant interaction with the target audience and to acquire rapid feedback (Yalçın and Ene, 2008: 246). In the study which has been prepared with these objectives, the virtual public relations activities of the most popular 20 companies of 2012 in Turkey, which they have performed via their corporate websites, will be studied in detail in terms of knowledge management process. Thus, it is aimed to instruct the corporations in relation to efficient management of constant knowledge flow, from both inside and outside of the corporation, in order for the corporations to be differentiated from their competitors in front of their target audience and to deliver successful results in their public relations activities. 


\subsection{Method of the Study}

In order to reach the goal of the study, the virtual public relations activities of the most popular 20 companies of 2012 in Turkey, which they have performed via their corporate websites, have been reviewed in terms of knowledge management process, by using inventional study model. The modelling of web analysis that is related to the study, is based on the studies of Nah et al. (2002) and Sayımer (2006) and a new model has been configured by expanding these studies. Afterwards, the virtual public relations activities of the corporations are analysed by using content analysis, in terms of three phases ("dissemination of knowledge", "knowledge acquisition", "knowledge sharing") that make up the knowledge management process on the web.

Content analysis is a study technique that enables the communication content to be performed systematically, generally within the scope of predetermined classifications (categories). The most important reason of its popular usage is that the knowledge with rich content is revealed by means of standard labels (Altunışık et al., 2001: 226). Content can be all kinds of content, both textual; like the articles in the newspapers and visual; auditory, like TV and radio shows, movies and documentaries, group discussions, musical recordings, advertisements, video games and web sites (Kurtuluş, 2010: 51; Geray, 2011: 151; Bilgin, 2006: vii; Aziz, 2011: 135). Nevertheless, content analysis is a convenient tool for many descriptive and descriptive studies. Moreover, content analysis can be performed qualitatively and quantitatively and in the manner that it includes the mixture of both methods (Erdoğan, 1998: 81; Altunışık et al., 2001: 223-224).

The emergence of content analysis notion in the communication studies goes back a long way. In 1910, Max Weber, a popular sociologist, suggested to use this technique in order to determine how much the newspapers concentrate on social and political events. Weber's suggestion can be the start of "making a current issue", due to the fact that it tried to answer the question of what the newspapers put on the headlines (Gunter, 2002: 220-221). Therefore, content analysis has emerged, among social science study techniques, as a technique which has been used oriented at the content in mass media tools and later, contents, such as individual (psychological) and corporative (i.e. Education fields), have started to use this technique (Geray, 2011: 151). With this purpose in mind, this study has researched the virtual public relations activities of corporations by performing content analysis, in the context of knowledge management processes on the web environment.

\subsection{Sample of the Study}

For this study, it has been decided to consider the analysis sample of 2012 results of monthly business and economics magazine Capital's study, which focuses on most popular companies of Turkey by conducting a survey with 1555 managers. In this study, which is limited with the 2012's most popular 20 companies in Turkey, aforesaid companies represent different sectors and are among the biggest companies in Turkey, in terms of turnover and profitability. These companies are, respectively, as follows: Turkcell, Garanti Bankası, Coca-Cola, Arçelik, Koç Holding, Unilever, Türkiye İş Bankası, Procter \& Gamble, Eczacıbaşı Group, Turkish Airlines, Doğuş Group, Microsoft, Sabancı Holding, Borusan Holding, Ülker, Tüpraş, Mercedes Benz Türk, Vodafone, Akbank, BSH (Bayıksel and Fırat, 2012).

It will be presented how these companies, which are among the most successful companies in Turkey in terms of turnover and profitability, have managed to reach this level of success in interactive management of virtual public relations activities, performed via their web sites.

\subsection{Content Analysis of Corporate Web Sites}

In order to perform content analysis in the context of this study, Turkish web sites of the companies, which were listed under the Google search engine, performed between June $1^{\text {st }}$ - $20^{\text {th }} 2013$, were found. Afterwards, the corporate web sites of 2012's most popular 20 companies in Turkey were analysed in terms of specific features related to knowledge management phases and these findings are shown by putting an " $X$ " mark across the web sites that possess these features on Table 1, Table 2 and Table 3. 
Table 1. Dissemination of Knowledge from the Web Sites of Corporations

\begin{tabular}{|c|c|c|c|c|c|c|c|c|c|c|c|c|c|}
\hline Companies & 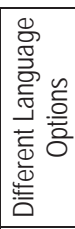 & 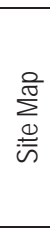 & 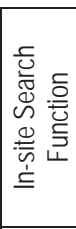 & 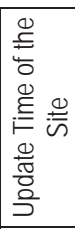 & 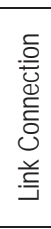 & 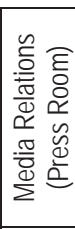 & 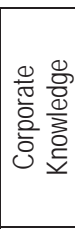 & 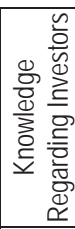 & 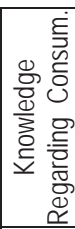 & 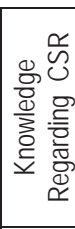 & 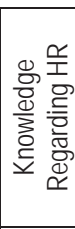 & 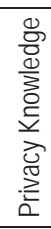 & 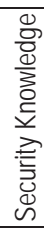 \\
\hline Turkcell & $x$ & $\mathrm{X}$ & $x$ & & $\mathrm{X}$ & $x$ & $x$ & $x$ & $x$ & $x$ & $x$ & $\mathrm{X}$ & $\mathrm{X}$ \\
\hline Garanti Bankası & $x$ & $\mathrm{X}$ & $x$ & & $\mathrm{X}$ & $x$ & $x$ & $x$ & $x$ & $x$ & $x$ & $\mathrm{X}$ & $\mathrm{X}$ \\
\hline Caca-Cola Turkey & & & & & $\mathrm{X}$ & & & & $\mathrm{X}$ & & & $\mathrm{X}$ & \\
\hline Arçelik & $x$ & $\mathrm{X}$ & $\mathrm{X}$ & & $\mathrm{X}$ & $\mathrm{X}$ & $\mathrm{X}$ & $x$ & $\mathrm{X}$ & $x$ & $x$ & $\mathrm{X}$ & $\mathrm{X}$ \\
\hline Koç Holding & $x$ & $\mathrm{X}$ & $x$ & $x$ & $\mathrm{X}$ & $x$ & $x$ & $x$ & $x$ & $x$ & $x$ & $\mathrm{X}$ & \\
\hline Unilever Turkey & & $\mathrm{X}$ & $\mathrm{X}$ & $x$ & $\mathrm{X}$ & $\mathrm{X}$ & $\mathrm{X}$ & $\mathrm{X}$ & $\mathrm{X}$ & $\mathrm{X}$ & $\mathrm{X}$ & $\mathrm{X}$ & \\
\hline Türkiye İş Bankası & $\mathrm{X}$ & $\mathrm{X}$ & $\mathrm{x}$ & & $\mathrm{X}$ & & $\mathrm{x}$ & $\mathrm{x}$ & $\mathrm{X}$ & $\mathrm{X}$ & $\mathrm{x}$ & $\mathrm{X}$ & $\mathrm{X}$ \\
\hline Procter\&Gamble Turkey & & $\mathrm{X}$ & & & & & $x$ & & $\mathrm{x}$ & $\mathrm{x}$ & $x$ & $\mathrm{X}$ & \\
\hline Eczacıbaşı Group & $x$ & & $x$ & & $\mathrm{X}$ & $x$ & $x$ & $x$ & $x$ & $x$ & $x$ & & \\
\hline Turkish Air Lines & $X$ & & $X$ & & $\mathrm{X}$ & $x$ & $x$ & $x$ & $x$ & & $x$ & $\mathrm{X}$ & \\
\hline Doğuş Group & $\mathrm{X}$ & $\mathrm{X}$ & $x$ & & $\mathrm{X}$ & $x$ & $x$ & $x$ & $x$ & $x$ & $x$ & & \\
\hline Microsoft Turkey & & $\mathrm{X}$ & $\mathrm{x}$ & $\mathrm{x}$ & $\mathrm{X}$ & $\mathrm{X}$ & $\mathrm{x}$ & & $\mathrm{x}$ & & & $\mathrm{X}$ & $\mathrm{X}$ \\
\hline Sabancı Holding & $\mathrm{X}$ & & $x$ & & & $x$ & $x$ & $x$ & & $x$ & $x$ & $\mathrm{X}$ & \\
\hline Borusan Holding & $\mathrm{X}$ & & $\mathrm{X}$ & & & $\mathrm{X}$ & $\mathrm{X}$ & $\mathrm{X}$ & $\mathrm{X}$ & $\mathrm{X}$ & $\mathrm{X}$ & & \\
\hline Ülker & $x$ & $\mathrm{X}$ & $x$ & & $\mathrm{X}$ & $x$ & $x$ & $x$ & $x$ & $x$ & $x$ & $X$ & \\
\hline Tüpraş & $x$ & $x$ & $x$ & & $x$ & $x$ & $x$ & $x$ & $x$ & $x$ & $x$ & & \\
\hline Mercedes Benz Türk & & $\mathrm{X}$ & $\mathrm{X}$ & & & & $\mathrm{x}$ & & $\mathrm{x}$ & $\mathrm{x}$ & $\mathrm{x}$ & $\mathrm{X}$ & \\
\hline Vodafone Turkey & & $\mathrm{X}$ & $\mathrm{X}$ & & & $\mathrm{X}$ & $\mathrm{X}$ & & $\mathrm{X}$ & $\mathrm{x}$ & $\mathrm{x}$ & $\mathrm{X}$ & \\
\hline Akbank & $\mathrm{X}$ & $\mathrm{X}$ & $\mathrm{X}$ & & $\mathrm{X}$ & & $\mathrm{X}$ & $\mathrm{x}$ & $\mathrm{X}$ & $\mathrm{x}$ & $\mathrm{x}$ & & $\mathrm{X}$ \\
\hline BSH & & $\mathrm{X}$ & & & $\mathrm{X}$ & $x$ & $\mathrm{x}$ & $\mathrm{x}$ & & $x$ & $x$ & & \\
\hline TOTAL & 13 & 15 & 17 & 3 & 15 & 15 & 19 & 15 & 18 & 17 & 18 & 14 & 6 \\
\hline Percentage Rate & 65 & 75 & 85 & 15 & 75 & 75 & 95 & 75 & 90 & 85 & 90 & 70 & 30 \\
\hline
\end{tabular}

Table 2. Corporation Knowledge Acquisition via Web Sites

\begin{tabular}{|c|c|c|c|c|}
\hline Companies & 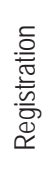 & 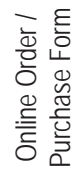 & 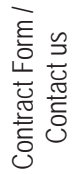 & 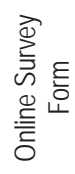 \\
\hline Turkcell & $\mathrm{X}$ & $X$ & $X$ & \\
\hline Garanti BankasI & $x$ & & $X$ & \\
\hline \multicolumn{5}{|l|}{ Caca-Cola Turkey } \\
\hline Arçelik & $X$ & $x$ & $x$ & \\
\hline Koç Holding & & & $\mathrm{X}$ & \\
\hline Unilever Turkey & & & $x$ & \\
\hline Türkiye İş Bankası & $x$ & & $x$ & \\
\hline Procter\&Gamble & & & $\mathrm{X}$ & \\
\hline Eczacıbaşı Group & $\mathrm{X}$ & & $\mathrm{X}$ & \\
\hline Turkish Airlines & $\mathrm{X}$ & $x$ & $x$ & \\
\hline Doğuş Group & & & $x$ & \\
\hline Microsoft Turkey & & $x$ & $\mathrm{X}$ & \\
\hline Sabancı Holding & & & $X$ & \\
\hline Borusan Holding & & & $\mathrm{X}$ & \\
\hline Ülker & $\mathrm{X}$ & & $\mathrm{X}$ & \\
\hline Tüpraş & & & $x$ & \\
\hline Mercedes Benz Türk & & & $\mathrm{X}$ & \\
\hline Vodafone Turkey & $\mathrm{X}$ & & $X$ & \\
\hline
\end{tabular}




\begin{tabular}{|c|c|c|c|c|}
\hline Akbank & $X$ & & $X$ & \\
\hline BSH & $X$ & & $X$ & \\
\hline TOTAL & 10 & 4 & 19 & 0 \\
\hline Percentage rate & 50 & 20 & 95 & 0 \\
\hline
\end{tabular}

Table 3. Knowledge Sharing of Corporations

\begin{tabular}{|c|c|c|c|c|c|c|c|c|c|c|c|}
\hline Companies & 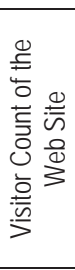 & 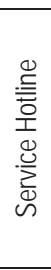 & 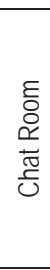 & 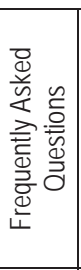 & 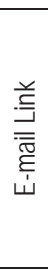 & 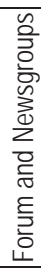 & 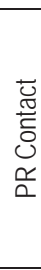 & 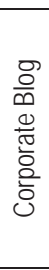 & 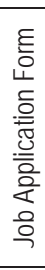 & 壱 & 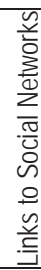 \\
\hline Turcell & & $X$ & & $X$ & $X$ & & & $X$ & $\mathrm{X}$ & & $X$ \\
\hline Garanti Bankası & & & & $X$ & $X$ & & & & $\mathrm{X}$ & & $X$ \\
\hline Caca-Cola Turkey & & & & & & & & & & $X$ & $X$ \\
\hline Arçelik & & $X$ & & $\mathrm{X}$ & $X$ & & & & $X$ & $X$ & $X$ \\
\hline Koç Holding & & & & & & & & & $X$ & & $X$ \\
\hline Unilever Turkey & & & & & $X$ & & $X$ & & $\mathrm{X}$ & & $X$ \\
\hline Türkiye Iş Bankası & & $\mathrm{X}$ & & $X$ & & & & & $\mathrm{X}$ & & $X$ \\
\hline $\begin{array}{c}\text { Procter\&Gamble } \\
\text { Turkey }\end{array}$ & & $X$ & & $x$ & & & & & $x$ & & \\
\hline Eczacıbaşı Group & & $X$ & & & & & & & $X$ & & $x$ \\
\hline Turkish Airlines & & $\mathrm{X}$ & & $\mathrm{X}$ & & & & & $\mathrm{X}$ & & $x$ \\
\hline Doğuş Group & & & & & & & & & $\mathrm{X}$ & & \\
\hline Microsoft Turkey & & $\mathrm{X}$ & $X$ & $x$ & & & & $x$ & $x$ & & $X$ \\
\hline Sabancı Holding & & & & & & & & & $X$ & & $X$ \\
\hline Borusan Holding & & & & $X$ & & & & & $X$ & & $X$ \\
\hline Ülker & & $X$ & & $\mathrm{X}$ & & & & & $\mathrm{X}$ & & $x$ \\
\hline Tüpraş & & & & $\mathrm{X}$ & $x$ & & & & $\mathrm{X}$ & & \\
\hline Mercedes Benz Türk & & $X$ & & & & & & $X$ & $X$ & $X$ & $X$ \\
\hline Vodafone Turkey & & & $X$ & $X$ & & $X$ & & & $\mathrm{X}$ & & $X$ \\
\hline Akbank & & $X$ & & $X$ & & & & & $\mathrm{X}$ & & $X$ \\
\hline $\mathrm{BSH}$ & & & & & & & & & $\mathrm{X}$ & & \\
\hline TOTAL & 0 & 10 & 2 & 12 & 5 & 1 & 1 & 3 & 19 & 3 & 16 \\
\hline Percentage Rate & 0 & 50 & 10 & 60 & 25 & 5 & 5 & 15 & 95 & 15 & 80 \\
\hline
\end{tabular}

\subsection{Findings of the Study}

In this study, virtual public relations activities, which were examined by the means of their corporate web sites, of 2012's most popular 20 companies in Turkey, were analysed in terms of knowledge management phases, as seen in Table 1, Table 2 and Table 3, by using content analysis. Relevant results regarding the dissemination of knowledge from the corporations' web sites are as follows:

As seen in Table 1, 95\% of the 20 companies include corporate knowledge, 90\% of them include knowledge regarding consumers and human resources, $85 \%$ include in-site search function on their web sites and knowledge regarding corporate social responsibility, $75 \%$ of them include site map, link connection, media relations and knowledge regarding investors, $70 \%$ include privacy knowledge, $65 \%$ include various language options, $30 \%$ of them include security knowledge and $15 \%$ include site update knowledge.

Relevant results regarding the Corporations' knowledge acquisition via their web sites are as follows:

As seen in Table 2, 95\% of the 20 companies include contact forms, 50\% include registration, $20 \%$ include online order/purchase form on their web sites. Survey form is found on none of the web pages of the companies studied.

And relevant results regarding the corporations' knowledge sharing is as follows:

As seen in Table 3, 95\% of the 20 companies include job application form, 80\% include links to social networks belonging to the corporations (Facebook, Twitter, Linkedin, Flickr, etc.), $60 \%$ include frequently asked questions, 50\% 
include service hotline, 25\% include e-mail links, 15\% include corporate blog and fun, 10\% include chat rooms and 5\% include forum and chat rooms and PR contact on their web sites. Visitor count knowledge is found on none of the company web sites.

\section{Conclusion and Assessment}

In the Internet environment, public relations increase the recognition of corporations and contribute positively to the corporation image. Therefore, the Internet, with its flexible structure, interaction environment it provides and diversity, present big opportunities for public relations. Herein, it is important for the public relations to apprehend the Internet with its dimension to communicate and to use this environment in the most effective way. In this regard, public relations pragmatists show interest to Internet environment and particularly to the web sites in recent years.

Corporate web sites provide opportunities, such as faster and easier dissemination of company knowledge, the ability to make research regarding the target audience, publication of corporate bulletin and means to act as a public relations tool with all these features (Sayımer, 2006: 164). Besides, making a connection with target audience through a corporate web site will help to align the corporate policies and public requests and expectations. Moreover, the target audience who are informed through the web sites will feel like a partner of the corporation due to this interactive environment. Consequently, public relations pragmatists will have to establish and develop web sites that put the spotlight on the corporation, enable a two-way communication with target audience and increase the awareness on target audience. However, the important factor here is to provide knowledge to the target audiences and to develop strategies that will improve the relations with them.

In this study, where the knowledge management structures of these sites' overviews are presented and based upon the virtual public relations applications of 2012's most popular 20 companies in Turkey, in order for the abovementioned corporations to recognize their positive and negative aspects, along with differentiating themselves from the competitors in front of their target audience and to gain efficient results in their public relations activities, it is intended to guide the corporations in terms of constant knowledge coming from inside and outside of the corporation. When compared in terms of dissemination of knowledge, knowledge acquisition and knowledge sharing, it is seen that 20 companies, which are analysed in the context of the study, place less emphasis on applications regarding the knowledge sharing and more emphasis on applications regarding dissemination of knowledge and knowledge acquisition. Therefore, it can be said that those corporations which desire to be more successful in public relations activities, need to place more emphasis on applications that are related to knowledge sharing on their web sites.

As a continuation of this study, corporate web sites, as public relations tools for the companies that exist on certain sectors, can be analysed with content analysis in terms of knowledge management process. Thus, it will be possible to specify in which sector the corporate websites, as a means of public relations, create more interaction with the target audience in terms of "dissemination of knowledge", "knowledge acquisition" and "knowledge sharing", which constitute the three significant steps of knowledge management process.

\section{References}

Alan, Aygül Ernek, Elif Sungur, (Bahar 2007). "Kurum Kültürünün Görsel Kimliğe Yansıması: Web Sitelerinde Görsel kimlik Kullanımı", Yeditepe Üniversitesi lletişim Çalışmaları Dergisi, 5: 129-147.

Alikılıç, Özlem Aşman, (2011). Halkla llişkiler 2.0: Sosyal Medyada Yeni Paydaşlar, Yeni Teknikler, Efil Yayınevi, Ankara.

Altunışık, Remzi, Recai Coşkun, Engin Yıldııım, Serkan Bayraktaroğlu, (2001). Sosyal Bilimlerde Araşıırma Yöntemleri: SPSS Uygulamalı, Sakarya Kitabevi, Adapazarı.

Aziz, Aysel, (2011). Sosyal Bilimlerde Araştırma Yöntemleri ve Teknikleri, Nobel Akademik Yayıncılık Eğitim Danışmanlık Tic. Ltd. Şți, Ankara.

Barutçugil, İsmet, (2002). Bilgi Yönetimi, Kariyer Yayıncılık Illetişim, Eğitim Hizmetleri Ltd. Şti., İstanbul.

Bayıksel, Şeyma Öncel, Ebru Fırat, (2012). "Zirveye Taşıyan Kriterler", http://www.capital.com.tr/zirveye- tasiyan-kriterlerhaberler/25028.aspx, (25.08.2013).

Bilgin, Nuri, (2006). Sosyal Bilimlerde İ̧̧erik Analizi: Teknikler ve Örnek Çalışmalar, Siyasal Kitabevi, Ankara.

Canöz, Kadir, (2008). "Bilgi Toplumu ve Halkla Illiskiler", Halkla Illişkiler, Ahmet Kalender ve Mehmet Fidan (Ed.), Tablet Yayınları, Konya, 341-389.

Clarke, Thomas, (2001). "The Knowledge Economy", Education+Training, 43(4-5): 189-196.

Çetinkaya, Ahmet, (2012). "Örgütsel Bilgi Yönetim Sürecinde Bilgi Yönetim Performansı Boyutları: Ölçek Geliştirme ve Geçerliliği Üzerine Bir Araştırma", Öneri Dergisi, 10(38): 157-162.

Davenport, Thomas H., Laurence Prusak, (2001). İ̧ Dünyasında Bilgi Yönetimi, Rota Yayınları, İstanbul. 
Er, Gamze, (2008). Sanal Ortamda Itibar Yönetimi, Cinius Yayınları, İstanbul.

Erdoğan, İfan, (1998). SPSS Kullanım Örnekleriyle Araştırma Dizaynı ve İstatistik Yöntemleri, Emek Matbaası, Ankara.

Falk, Louis K. (Winter 2000). "Creating a Winning Website", The Public Relations Strategist, 5(4): 37-40.

Fırlar, F. Belma, (2010). "Kurumsal Sosyal Sorumluluk ve Web Siteleri", Yeni Iletişim Ortamları ve Etkileşim Uluslararası Konferansı, 2830 Nisan, İstanbul-Türkiye,154-162.

Filius, Renee, Jan A. de Jong, Erik C. Roelofs, (2000). "Knowledge Management in the HRD Office: A Comparison of Three Cases", Journal of Workplace Learning, 12(7): 286- 295.

Geray, Haluk, (2011). Toplumsal Araştırmalarda Nicel ve Nitel Yöntemlere Giriş: Iletişim Alanından Örneklerle, Genesis Kitap, Ankara.

Göksel, Ahmet Bülend, E. Pelin Baytekin, (2008), "Bilgi Toplumunda İşletmeler Açısından Önemli Bir Zenginlik: Entelektüel Sermaye Halkla llişkiler Açısından Bir Değerlendirme-, İstanbul Üniversitesi Iletişim Fakültesi Dergisi, 31: 81-90.

Gunter, Barrie, (2002). "The Quantitative Research Process", A Hanbook of Media and Communication Research Qualitative and Quantitative Methodologies, Klaus Bruhn Jensen (Ed.), Routledge, London, 209-234, http://books.google.com.tr, (31.05.2013).

Güçdemir, Yeşim, (2010). Sanal Ortamda Illetişim: Bir Halkla llişskiler Perspektifi, Derin Yayınları, İstanbul.

Halligan, Brian, Dharmesh Shah, (2010). Inbound Marketing: Get Found Using Google, Social media and Blogs, John Wiley,\& Sons, Inc. New Jersey, http://books.google.com.tr/books?hl=tr\&id= VKwD8|KzeEoC\&q=Wellesley+\#v=snippet\&q=Wellesley\&f=false, (05.06.2013).

Hill, Laura Newland, Candace White, (Spring 2000). "Public Relations Practitioners' Perception of the World Wide Web as a Communications Tool", Public Relations Review, 26(1): 31-51.

Jo, Samsup, Jaemin Jung, (2005). "A Cross Cultural Study of the Word Wide Web and Public Relations", Corporate Communications:An International Journal, 10(1): 24-40.

Karakaş Bülent, Aysun Yaralı, (2004). "Kamu Yönetiminden Bilgi Yönetimine", Osmangazi Üniversitesi, İktisadi İdari Bilimler Fakültesi, III. Ulusal Bilgi, Ekonomi ve Yönetim Kongresi, 25-26 Kasım, Eskişehir, 547-555.

Kurtuluş, Kemal, (2010). Araştırma Yöntemleri, Türkmen Kitabevi, İstanbul.

Malhotra, Yogesh, (2003). "Is Knowledge the Ultimate Competitive Advantage?", Business Management Asia, September, Q 3/4: 66-69.

Nah, Fiona, Keng Siau, Yuhong Tian, Min Ling, (2002). "Knowledge Management Mechanisms in E-Commerce: A Study of Online Retailing and Auction Sites", Journal of Computer Information Sysytems, 42(5): 119-128.

Odabaş, Hüseyin, (2003). "Kurumsal Bilgi Yönetimi", Türk Kütüphaneciliği, 17(4): 357-368.

Okay, Aydemir, Nesrin Canpolat, (2006). Halkla Ilişkiler ve Hedef Kitleyle Iletişimde Kurumsal Web Sitelerinin İncelenmesi", Yeni Iletişim Ortamları ve Etkileşim Uluslararası Konferansı, 1-3 Kasım, İstanbul-Türkiye, 441-455.

Özkaya, Betül, (2012). "Halkla llişkiler 2.0 Kapsamında Kurumların Arama Motoru Kullanııılarına Yönelik Çalışmaları", Marmara Üniversitesi İktisadi ve İari Bilimler Dergisi, 33(2): 355-382.

Özkaya, Betül, (2010). "Reklam Aracı Olarak Advergaming", Marmara Üniversitesi, İktisadi ve İdari Bilimler Fakültesi Dergisi, 29(2): 455478.

Robbins, Stephanie S., Antonis C. Stylianou, (2003). "Global Corporate Web Sites:An Emprical Investigation of Content and Design", Information and Management, 40(3): 205-212.

Sabuncuoğlu, Zeyyat, (1998). İşletmelerde Halkla Ilişkiler, Ezgi Kitabevi Yayınları, Bursa.

Sayımer, İdil, (2008). Sanal Ortamda Halkla Ilişkiler, Beta Basım Yayım Dağıım A.Ş., İstanbul.

Sayımer, İdil, (2006). "Halkla Illişkilerde Hedef Kitlelerle Çift Yönlü Simetrik Iletişim Kurmak Amacıyla Web Siteleri Kullanımı", Yeni İletişim Ortamları ve Etkileşim Uluslararası Konferansı, 1-3 Kasım, İstanbul-Türkiye, 163-172.

Scott, David Meerman, (2009). Pazarlamanın ve Iletişimin Yeni Kuralları, MediaCat Yayınları, İstanbul.

Selvi, Özgür, (Mart 2011). "Bilgi Toplumu, Bilgi Yönetimi ve Halkla Illişkiler", Gümüşhane Üniversitesi Illetişim Fakültesi Elektronik Dergisi, 3: $191-214$.

Şencan, Erdal, (2013). Bilgi Yönetimi ve Sanal Halkla Ilişkiler, Eğitim Yayınevi, Konya.

Taş, I. Ethem, Gözde Kestellioğlu, (2011). "Halkla Illşskilerde İnternetin Yeri ve Önemi", Kahraman Maraş Sütçü İmam Üniversitesi İktisadi ve İdari Bilimler Fakültesi Dergisi, 1(1): 73-92.

Theaker, Alison, (2006). Halkla Ilişkiler El Kitabı, MediaCat Yayınları, İstanbul.

Türk, Sezai, Ahmet Güven, (2007). Yeni Başlayanlar İçin Halkla llişkiler, Gazi Kitabevi, Ankara.

Uçak, Nazan Özenç, Tolga Çakmak, (2009). "Web Sayfası Kullanılabilirliğinin Ölçülmesi: Hacettepe Üniversitesi Bilgi ve Belge Yönetimi Bölümü Web Sayfası Örneği", Türk Kütüphaneciliği, 23(2): 278-298.

Wiig, Karl M. (1997). "Knowledge Management: An Introduction and Perspective", The Journal of Knowledge Management, 1(1): 6-14.

Yalçın, Asuman, Selda Ene, (2008). "Rekabet Ortamında Başarı Sağlamak İsteyen On-Linne İşletmelerde Bilgi Yönetimi Yapısının İncelenmesi", Türkiye Biliş̧im Derneği 2. İstanbul Bilişim Kongresi, 3-4 Haziran, İstanbul, 241-254.

Yeygel, Sinem, (2005). "Şirketlerin Kurum Kimliklerini Yansıtan Bir Ortam Olarak Web Siteleri", Yeni Düşünceler, 1(1):77-91.

Yılmaz, Elgiz, (2011). "Yeni Medya ve Halkla Ilişkiler: Hedef Kitleye Ağ Üzerinden Erişmek", Dünden Bugüne Halkla llişkiler, Metin Işık ve Mustafa Akdağ (Ed.), Eğitim Akademi Yayınları, Konya, 137-176.

Yurdakul, Nilay Başok, (2006). "Internet ve Halkla Illişkiler", Bilgi Illetişim Teknolojileri ve Yansımaları, Beril Akıncı Vural (Ed.), Nobel Yayın Dağıtım, Ankara, 187-223.

Zaim, Halil, (2005). Bilginin Artan Önemi ve Bilgi Yönetimi, İ̧aret Yayınları, İstanbul. 